\title{
Raw Glycerol and Parboiled Rice Effluent for Carotenoid Production: Effect of the Composition of Culture Medium and Initial pH
}

\author{
Carolina Moroni Silva, Thais de Matos de Borba, Susana Juliano Kalil and \\ Janaína Fernandes de Medeiros Burkert* \\ Federal University of Rio Grande (FURG), Chemistry and Food School (EQA), PO Box 474, \\ BR-96203-900 Rio Grande, RS, Brazil
}

Received: August 27, 2015

Accepted: June 29, 2016

\begin{abstract}
Summary
Search for naturally grown food has stimulated the biotechnological production of carotenoids. Therefore, the use of the yeast Xanthophyllomonas dendrorhous has been researched due to its abilities to assimilate different sources as substrates and to produce high amounts of carotenoids. Furthermore, alternative sources have been used as the culture medium to reduce costs and environmental impact. A potent carotenoid is astaxanthin in view of its health-promoting and antioxidative properties. It consists of different geometrical isomers with trans and cis configuration. In X. dendrorhous this carotenoid is mostly found in the trans form, but cis isomers can also be found. Carotenoid production was investigated in culture medium containing by-products such as raw glycerol (from biodiesel) and parboiled rice effluent. The effects of the culture medium components on biomass concentration and specific and volumetric productions of carotenoids were verified by the Plackett-Burman design. Cultivations were carried out with yeast Xanthophyllomonas dendrorhous NRRL Y-17268 at $25^{\circ} \mathrm{C}$ and $150 \mathrm{rpm}$ for $168 \mathrm{~h}$. In this study, maximum production of carotenoids was obtained under the following conditions (in $\mathrm{g} / \mathrm{L}$ ): raw glycerol 10, glucose 10, yeast extract 10, malt extract 10 and peptone 1 at $\mathrm{pH}=6$. Resulting specific and volumetric productions of carotenoids were 326.8 and $4.1 \mu \mathrm{g} / \mathrm{g}$, respectively.
\end{abstract}

Key words: natural pigments, by-products, Plackett-Burman design, Xanthophyllomonas dendrorhous

\section{Introduction}

Carotenoids are some of the most important compounds found in food. These natural colorants are responsible for yellow, orange and red colors in many kinds of food and play a decisive role in their acceptability (1). Besides, they have several other benefits to health since they protect humans against certain forms of cancer, cardiovascular disease, cataracts and macular degeneration $(2-4)$.
Rise in consumers' health awareness has made them seek functional foods, a fact that may trigger an increase in the demand for carotenoids in the food industry (5). The global market demand for carotenoids has grown 2.9 $\%$ per year (6) and is expected to reach almost 10 million tons by 2017 (7). However, most of the commercial carotenoids derive from chemical synthesis and cannot meet consumers' demands for natural carotenoids (5). Due to concerns over the use of chemical additives in food, there has been an increasing interest in carotenoids that are naturally obtained by biotechnological processes. 
A large variety of substrates and microorganisms has been tested with special emphasis on the ever-increasing interest in the production of microbial carotenoids. Therefore, the yeast Phaffia rhodozyma (also referred to as Xanthophyllomonas dendrorhous) stands out as a natural source of carotenoids (8-12) due to its ability to assimilate different carbon sources as substrates, heterotrophic metabolism, relatively fast growth rate, ability to reach high cell density and nutrient quality and safety as a food additive. Besides, it has been certified as a GRAS (Generally Recognized as Safe) microorganism.

The production of bioproducts with alternative substrates, such as a source of carbon and/or nitrogen, is very important. Therefore, Brazil has the advantage of having various industrial by-products that can be used to add value, decrease the risk of having them discarded into the environment and reduce costs of medium production.

The effect of the experimental design methodology on the conditions of the process that involves the production of carotenoids has been studied $(6,13,14)$. In a previous study carried out by our research group, the production of carotenoids by the wild yeast Sporidiobolus pararoseus with the use of a complex medium containing by-products such as raw glycerol, corn steep liquor and sugar cane molasses was investigated (15). The production of carotenoids from Phaffia rhodozyma NRRL Y-17268 was investigated in a culture medium containing pure glycerol and raw glycerol as additional carbon sources (8) and parboiled rice effluent as nitrogen and phosphorus sources (16). Moreover, carotenoids produced by this yeast strain had antioxidant activity (expressed as Trolox equivalent) of 4.00 and $3.66 \mathrm{mM} / \mu \mathrm{g}$ in ABTS radical cation discoloration and ferric reducing antioxidant power assays, respectively (17). However, the combined use of both by-products as substrates in the culture medium to maximize the production of carotenoids by an experimental design has not been studied yet.

Therefore, the effect of the concentration of culture medium containing two agro-industrial by-products, raw glycerol and parboiled rice effluent, as sources of carbon and nitrogen, respectively, on carotenoid bioproduction by Xanthophyllomonas dendrorhous was studied to add value to these by-products, thus possibly reducing the cost of the culture medium.

\section{Materials and Methods}

\section{Alternative substrates}

Raw glycerol and parboiled rice effluent, which were used in this study as alternative sources of carbon and nitrogen, were supplied by industries located in the south of Brazil and previously characterized (8).

\section{Culture conditions and production of carotenoids}

The yeast Xanthophyllomonas dendrorhous NRRL Y-17268 used in this research was kept in $10 \mathrm{~mL}$ of yeast malt (YM) agar (18) with the addition of $10 \%$ (98 \% by mass) analytical grade glycerol (Synth, Diadema, Brazil) and stored at $-18^{\circ} \mathrm{C}$.
The inoculum was prepared by transferring $10 \mathrm{~mL}$ of the previously thawed microorganism suspension kept in analytical grade glycerol $\left(-18^{\circ} \mathrm{C}\right)$ to $90 \mathrm{~mL}$ of the modified YM medium (in $\mathrm{g} / \mathrm{L}$ : glucose 10, yeast extract 3, peptone 5, malt extract 3 and $\mathrm{KNO}_{3}$ 0.2) (19). It was incubated at $25^{\circ} \mathrm{C}$ and $150 \mathrm{rpm}$ for $48 \mathrm{~h}$ or for the time required for the cell count to be at least $10^{8}$ cells $/ \mathrm{mL}$, counted by a Neubauer chamber (Optik Labor, Lancing, UK) (9).

Bioproduction tests were conducted on an orbital shaker (model TE 425; Tecnal, Piracicaba, Brazil) with controlled stirring rate and temperature. Erlenmeyer flasks (500 mL) with $153 \mathrm{~mL}$ of culture medium were previously sterilized in an autoclave (model 103; Fabbe, São Paulo, Brazil) at $121^{\circ} \mathrm{C}$ for $15 \mathrm{~min}$. Each flask was inoculated with $17 \mathrm{~mL}$ of the previously prepared yeast suspension, which corresponds to $10^{7}$ cells/mL (20), and incubated at $25^{\circ} \mathrm{C}$ and $150 \mathrm{rpm}$ for $168 \mathrm{~h}$. Every $24 \mathrm{~h} 10-\mathrm{mL}$ samples were collected and centrifuged at $1745 \times g$ for 10 min for the analysis of the supernatant $(\mathrm{pH})$ and of the pellet (biomass and carotenoids).

\section{Experimental design}

In the experimental design, the effects of the concentration of the medium components and initial $\mathrm{pH}$ on carotenoid production were evaluated using the Plackett-Burman design, assuming that there are no interactions among the different variables $\left(\mathrm{x}_{\mathrm{i}}\right)$ in the studied range. $\mathrm{A}$ linear approach is considered to be sufficient for screening, according to the following equation:

$$
\mathrm{y}=\beta_{0}+\Sigma \beta_{\mathrm{i}} \mathrm{x}_{\mathrm{i}}(\mathrm{i}=1, \ldots, n)
$$

where $y$ is the estimated target function, $\beta_{\mathrm{i}}$ are the regression coefficients and $n$ is number of variables. The Plackett-Burman design is a fractional factorial design whose main effects may be simply calculated as the difference between the average value of the measurements made at the low level $(-1)$ of the factor and the average value of the measurements at the high level (+1) (21).

The independent variables (factors) under study were raw glycerol, parboiled rice effluent, glucose, yeast extract, malt extract, peptone and initial $\mathrm{pH}$ (Table 1). In this study, seven variables were screened in 12 assays with three central points (Table 2). The responses or dependent variables during $168 \mathrm{~h}$ of study were total carotenoids (in $\mu \mathrm{g} / \mathrm{mL}$ or $\mu \mathrm{g} / \mathrm{g}$ ) and biomass (in $\mathrm{g} / \mathrm{L}$ ).

Table 1. Levels of factors, concentrations of variables and $\mathrm{pH}$ values studied by Plackett-Burman design

\begin{tabular}{lccc}
\hline \multirow{2}{*}{ Variable } & \multicolumn{3}{c}{$\gamma /(\mathrm{g} / \mathrm{L})$} \\
\cline { 2 - 4 } Raw glycerol & Level -1 & Level 0 & Level +1 \\
Effluent & 10 & 25 & 40 \\
Glucose & 0 & 25 & 50 \\
Yeast extract & 1 & 5.5 & 10 \\
Malt extract & 1 & 5.5 & 10 \\
Peptone & 1 & 5.5 & 10 \\
pH & 1 & 5.5 & 10 \\
\hline
\end{tabular}




\section{pH determination}

The $\mathrm{pH}$ of the sample was determined by a potentiometer (model MB-10; Marte, São Paulo, Brazil), in accordance with the AOAC method no. 972.44 (22).

\section{Recovery and determination of total carotenoids}

Recovery of total carotenoids was carried out in agreement with the methodology adapted from Fonseca et al. (10). Cells were centrifuged at $1745 \times g$ for $10 \mathrm{~min}$, dried at $35^{\circ} \mathrm{C}$ for $48 \mathrm{~h}$ in an oven (Eletrolab, São Paulo, Brazil) and frozen (at $-18{ }^{\circ} \mathrm{C}$ for $48 \mathrm{~h}$ ) in a refrigerator (Consul, Joinville, Brazil). Afterwards, at room temperature, $2 \mathrm{~mL}$ of dimethylsulphoxide (DMSO; Synth, Diadema, Brazil) were added (previously heated at $55^{\circ} \mathrm{C}$ for $1 \mathrm{~h}$, in a water bath (model 102; Fanem, São Paulo, Brazil) to $0.05 \mathrm{~g}$ of dried and frozen cells and shaken on a vortex agitator (model QL-901; Biomixer, Ningbo, PR China) and left to rest for $30 \mathrm{~min}$.

After cell disruption, carotenoids were extracted by adding $10 \mathrm{~mL}$ of acetone (Synth). Then, centrifugation was conducted at $1745 \times g$ for $10 \mathrm{~min}$. The supernatant was separated and successive extractions were carried out until the solvent and cells were colorless. A volume of $20 \mathrm{~mL}$ of $\mathrm{NaCl}$ solution ( $20 \%$ by mass per volume) and $20 \mathrm{~mL}$ of petroleum ether (Synth) were added. After agitation and phase separation, excess water was removed with anhydrous sodium sulfate (Synth) and total carotenoids were determined in petroleum ether as astaxanthin by spectrophotometric reading (model SP-220; Biospectro, Zhejiang, PR China) at $\lambda=474 \mathrm{~nm}$ (23) with the molar absorption coefficient of $2100 \mathrm{~L} /(\mathrm{mol} \cdot \mathrm{cm})(24,25)$, according to the following equation:

$$
\mathrm{SPC}=\frac{A_{474 \mathrm{~nm}} \cdot V \cdot 100}{21 \cdot m}
$$

where SPC is the specific production of total carotenoids $(\mu \mathrm{g} / \mathrm{g}), A$ is the absorbance, $V$ is the filtrate volume $(\mathrm{mL})$, and $m$ is the dry cell mass ( $\mathrm{g}$ ).

Volumetric production of carotenoids $(\mathrm{VPC} /(\mu \mathrm{g} / \mathrm{mL}))$ was calculated from SPC $(\mu \mathrm{g} / \mathrm{g})$ and biomass concentration $(\mathrm{g} / \mathrm{mL})$.

\section{Determination of biomass}

Cell count was estimated by absorbance readings at $\lambda=620 \mathrm{~nm}$ (26). The conversion of absorbance into biomass concentration was performed using a previously determined standard curve.

\section{Statistical analysis}

A statistical analysis of the estimated effects of each variable was performed. All analyses were done at $90 \%$ confidence level $(p<0.1)$ by the STATISTICA v. 5.0 (StatSoft Inc., Tulsa, OK, USA) software.

\section{Results and Discussion}

\section{Carotenoid production kinetics}

Total nitrogen $(15.2 \mathrm{mg} / \mathrm{L})$ and phosphorus $(30.7$ $\mathrm{mg} / \mathrm{L}$ ) concentrations in parboiled rice effluent are in agreement with data found in the literature regarding this agro-industrial by-product (27). The carbon mass fraction $(44.4 \%)$ in raw glycerol used in this study was higher than the one (39\%) used by Chatzifragkou et al. (28) in the study of the ability of eukaryotic microorganisms to assimilate raw glycerol derived from biodiesel and convert it into products with high added value. Therefore, the concentrations of nitrogen and phosphorus essential for the cell growth of the parboiled rice effluent and the carbon mass fraction in raw glycerol influence the transformation of these materials into potential sources of such nutrients in the culture medium used in this study.

The determination of the C:N ratio is a way to explain the cell growth and carotenoid production. Results in Table 2 show that reduction of the nitrogen content stimulated the production of carotenoids (and increased the value of the C:N ratio). Vustin et al. (29) found that a C:N ratio above 5 improves the biosynthesis of carotenoids. However, this ratio, by itself, cannot explain cell growth and carotenoid production. Other nutrients, such as vitamins, amino acids and minerals, and the conditions of the process (temperature, $\mathrm{pH}$, oxygen content) exert strong influence on the metabolism of yeasts $(29,30)$. On the other hand, the trials with $\mathrm{C}: \mathrm{N}$ ratio under 5 had the worst performance (trials 7, 9 and 11). Similar results were observed by Rios et al. (16) with the same microorganism in the medium containing alternative carbon and nitrogen sources, but without raw glycerol.

Table 2 and Fig. 1 show a variation in the maximum biomass concentration obtained in the different trials using the Plackett-Burman design, from 2.4 (trial 11) to 17.2 $\mathrm{g} / \mathrm{L}$ (trial 10). Regarding the maximum production of carotenoids, SPC ranged from 113.5 (trial 11) to $326.8 \mu \mathrm{g} / \mathrm{g}$ (trial 8), whereas VPC ranged from 0.3 (trial 11) to $4.1 \mu \mathrm{g} /$ $\mathrm{mL}$ (trial 8).

Promising results of carotenoid production above 3.0 $\mu \mathrm{g} / \mathrm{mL}(200 \mu \mathrm{g} / \mathrm{g})$ in $168 \mathrm{~h}$, with the combination of the by-products raw glycerol and parboiled rice effluent at different concentrations, added to other medium components, as shown in trial 2 (in g/L: raw glycerol 40, parboiled rice effluent 50 , glucose 1 , yeast extract 10 , malt extract 1 , peptone 1 , initial $\mathrm{pH}=4$ ), trial 8 (in $\mathrm{g} / \mathrm{L}$ : raw glycerol 10, glucose 10, yeast extract 10, malt extract 10 , peptone 1 , initial $\mathrm{pH}=6$ ), trial 10 (in $\mathrm{g} / \mathrm{L}$ : raw glycerol 40 , glucose 1 , yeast extract 1 , malt extract 10 , peptone 10 , initial $\mathrm{pH}=6$ ) and central points 13,14 and 15 (in g/L: raw glycerol 25, parboiled rice effluent 25 , glucose 5.5 , yeast extract 5.5, malt extract 5.5, peptone 5.5, initial $\mathrm{pH}=5$ ) were achieved in this study.

In trial 8 (in g/L: raw glycerol 10, glucose 10, yeast extract 10, malt extract 10, peptone 1 , initial $\mathrm{pH}=6$ ), SPC was the highest, equal to $326.8 \mu \mathrm{g} / \mathrm{g}$ (Fig. 1c), whereas VPC was $4.1 \mu \mathrm{g} / \mathrm{mL}$ (Fig. 1e). The exponential growth phase occurred up to $120 \mathrm{~h}$, followed by the stationary phase up to $168 \mathrm{~h}$ (Fig. 1a), when maximum production of carotenoids was achieved, an evidence of the fact that carotenoid synthesis is not directly associated with cell growth of this yeast. Likewise, Chávez-Cabrera et al. (11) found that the concentration of total proteins and pigments shows opposing trends, implying that protein synthesis restriction, necessary for cell growth, stimulates carotenoid synthesis by X. dendrorhous. Liu and $\mathrm{Wu}$ (30) also observed that carotenoids are synthesized as secondary metabolites 
Table 2. Plackett-Burman design with real values, C:N ratio and responses for biomass concentration, specific production of carotenoids (SPC) and volumetric production of carotenoids (VPC) in $168 \mathrm{~h}$

\begin{tabular}{crrrrrrrrrrr}
\hline Assay & $\mathrm{X}_{1}$ & $\mathrm{X}_{2}$ & $\mathrm{X}_{3}$ & $\mathrm{X}_{4}$ & $\mathrm{X}_{5}$ & $\mathrm{X}_{6}$ & $\mathrm{X}_{7}$ & $\mathrm{C}: \mathrm{N}$ & $\mathrm{Y}_{1}$ & $\mathrm{Y}_{2}$ & $\mathrm{Y}_{3}$ \\
\hline 1 & 40 & 0 & 10 & 1 & 1 & 1 & 6 & 30.2 & 8.4 & 190.7 & 1.6 \\
2 & 40 & 50 & 1 & 10 & 1 & 1 & 4 & 9.2 & 16.3 & 204.1 & 3.3 \\
3 & 10 & 50 & 10 & 1 & 10 & 1 & 4 & 6.0 & 9.0 & 213.4 & 1.9 \\
4 & 40 & 0 & 10 & 10 & 1 & 10 & 4 & 10.0 & 5.7 & 201.3 & 1.1 \\
5 & 40 & 50 & 1 & 10 & 10 & 1 & 6 & 7.6 & 16.1 & 119.5 & 1.9 \\
6 & 40 & 50 & 10 & 1 & 10 & 10 & 4 & 8.0 & 14.7 & 171.0 & 2.5 \\
7 & 10 & 50 & 10 & 10 & 1 & 10 & 6 & 4.9 & 3.2 & 175.2 & 0.6 \\
8 & 10 & 0 & 10 & 10 & 10 & 1 & 6 & 6.9 & 12.7 & 326.8 & 4.1 \\
9 & 10 & 0 & 1 & 10 & 10 & 10 & 4 & 4.6 & 4.9 & 163.8 & 0.8 \\
10 & 40 & 0 & 1 & 1 & 10 & 10 & 6 & 8.8 & 17.2 & 221.9 & 3.8 \\
11 & 10 & 50 & 1 & 1 & 1 & 10 & 6 & 4.0 & 2.4 & 113.5 & 0.3 \\
12 & 10 & 0 & 1 & 1 & 1 & 1 & 4 & 13.1 & 5.9 & 187.3 & 1.1 \\
13 & 25 & 25 & 5.5 & 5.5 & 5.5 & 5.5 & 5 & 7.7 & 15.1 & 210.1 & 3.2 \\
14 & 25 & 25 & 5.5 & 5.5 & 5.5 & 5.5 & 5 & 7.7 & 16.0 & 224.4 & 3.6 \\
15 & 25 & 25 & 5.5 & 5.5 & 5.5 & 5.5 & 5 & 7.7 & 15.5 & 201.0 & 3.1 \\
\hline
\end{tabular}

$\mathrm{X}_{1}=$ raw glycerol $(\mathrm{g} / \mathrm{L}), \mathrm{X}_{2}=$ effluent $(\mathrm{g} / \mathrm{L}), \mathrm{X}_{3}=$ glucose $(\mathrm{g} / \mathrm{L}), \mathrm{X}_{4}=$ yeast extract $(\mathrm{g} / \mathrm{L}), \mathrm{X}_{5}=$ malt extract $(\mathrm{g} / \mathrm{L}), \mathrm{X}_{6}=$ peptone $(\mathrm{g} / \mathrm{L}), \mathrm{X}_{7}=$ initial $\mathrm{pH}$, $\mathrm{Y}_{1}=$ biomass $(\mathrm{g} / \mathrm{L}), \mathrm{Y}_{2}=\mathrm{SPC}(\mu \mathrm{g} / \mathrm{g})$ and $\mathrm{Y}_{3}=\mathrm{VPC}(\mu \mathrm{g} / \mathrm{mL})$

by $X$. dendrorhous, especially when cells are under stress (nutrient limitation) and when cell growth (primary metabolism) is suppressed.

VPC (Figs. 1e and $\mathrm{f}$ ) trend was similar to biomass production (Figs. 1a and b), since it presents a relationship between SPC and cell count.

Good reproducibility of the carotenoid bioproduction can be verified in trials 13,14 and 15 (central points) of the Plackett-Burman design (Table 2 and Fig. 1).

The $\mathrm{pH}$ curves are shown in Figs. $1 \mathrm{~g}$ and $\mathrm{h}$. Depending on the composition of the medium culture and process conditions during its growth, the yeast $X$. dendrorhous can excrete carbonic intermediaries, such as acetic acid, an alcohol or an intermediate of the citric acid cycle that is subsequently reabsorbed, thus stimulating carotenogenesis (31) and influencing $\mathrm{pH}$ decrease in the first $24 \mathrm{~h}$ of cultivation. This behavior was better represented in trial 8 (Fig. 1g), according to the SPC peak observed (Fig. 1c) at $168 \mathrm{~h}$.

\section{Effect of the culture medium composition on carotenoid production}

Fig. 2 shows the analysis of the main effects of the variables on the biomass concentration, SPC and VPC during $168 \mathrm{~h}$ of cultivation using the Plackett-Burman design, which was performed at a $90 \%$ confidence level $(p<0.1)$. Increasing the raw glycerol concentration from 10 to $40 \mathrm{~g} / \mathrm{L}$ had significant effect on the biomass concentration and VPC, leading to an average increase of $6.7 \mathrm{~g} / \mathrm{L}$ and $0.9 \mu \mathrm{g} / \mathrm{mL}$, respectively. Glucose had negative effect when the medium concentration was increased from 1 to $10 \mathrm{~g} / \mathrm{L}$. It decreased biomass concentration to $1.5 \mathrm{~g} / \mathrm{L}$, but increased SPC to $44.7 \mu \mathrm{g} / \mathrm{g}$.

It is likely that these effects happened because glucose and raw glycerol are metabolized quickly. Glycerol passes through the cell membrane by facilitated diffusion (32). Inside the cell and under the conditions without nitrogen, it causes stress to the red yeast, thus stimulating carotenoid and other secondary (as well as primary) metabolite production $(33,34)$. Therefore, the energy for efficient acetyl-CoA and NADPH synthesis required for increased carotenoid production may derive from the catabolism of glycerol via glycolysis (34).

Bellou et al. (35) found that the use of glycerol by Mortierella ramanniana did not alter the amounts of biomass in comparison with other strains of Mortierella cultivated on multiple carbon sources. However, these fungi accumulated more interesting compounds (lipids) whose production was associated with primary metabolism during mycelial growth. In the yeast Yarrowia lipolytica, higher assimilation rates of glycerol than of glucose were also observed (36). However, they were not significantly affected by the increase in dissolved oxygen concentration (37).

Under aerobic conditions and easily metabolizable high levels of sugars, Deken (38) found that the Crabtree effect occurs and results not only in the decrease of biomass production but also in ethanol and acetic acid formation. Rivaldi et al. (39) showed that the route of glycerol assimilation is similar to the glycolysis, since the oxidation of glycerol by yeast consists in the phosphorylation of glycerol by the glycerol kinase enzyme to form glycerol-3-phosphate, which is reduced to dihydroxyacetone phosphate and is considered an important intermediate to a gluconeogenesis molecule (hexose synthesis), and to obtain a number of compounds by oxidative pathways.

Reynders et al. (40) also observed the Crabtree effect in fed-batch fermentation by Phaffia rhodozyma. In fed-batch culture at feed concentrations of 27 and $55 \mathrm{~g} / \mathrm{L}$ of glucose, there was a good agreement between the result- 

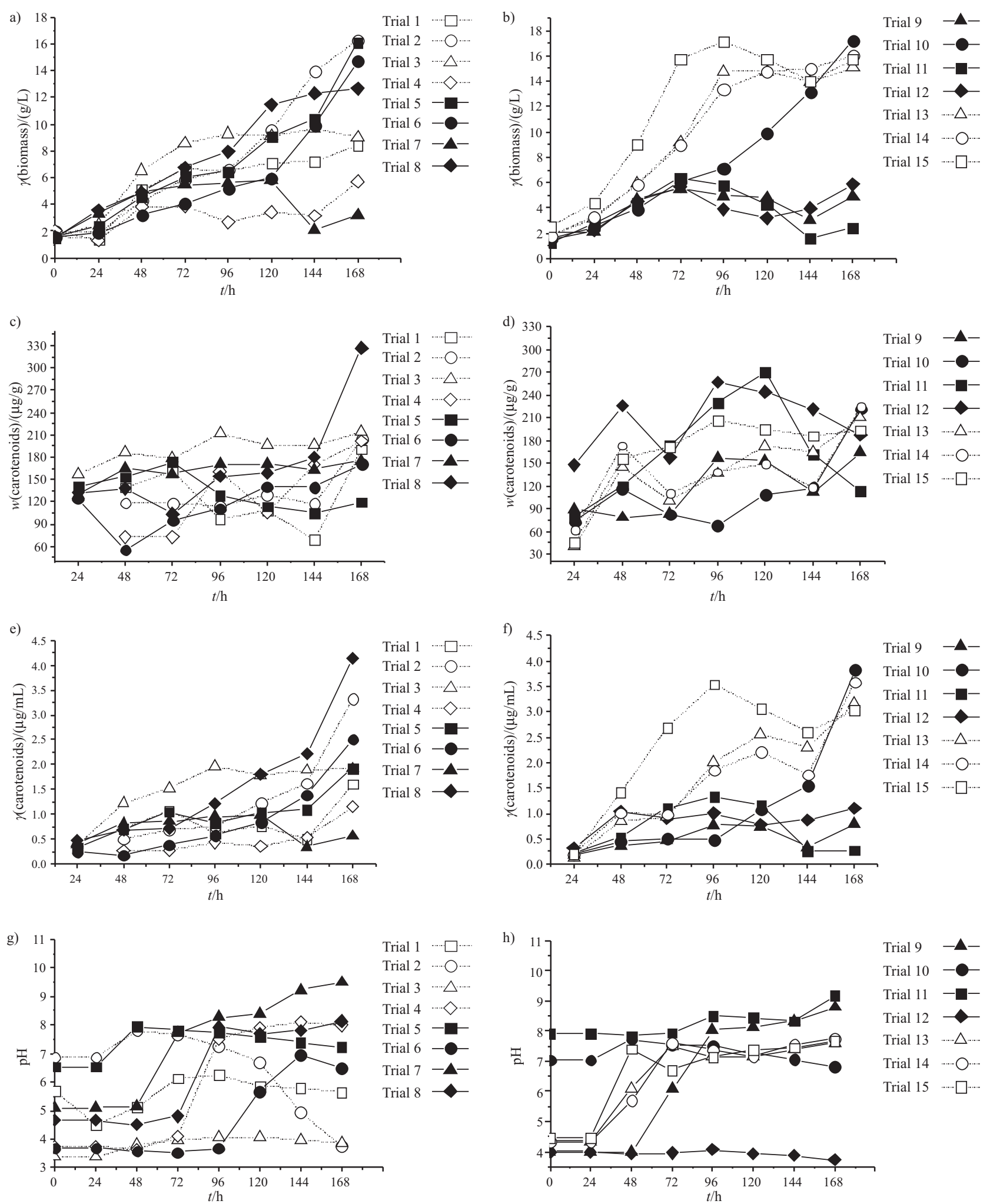

Fig. 1. Carotenoid production kinetics determined by the Plackett-Burman design at $25^{\circ} \mathrm{C}$ and $150 \mathrm{rpm}$ : a and b) biomass concentration, c and d) specific production of carotenoids ( $\mu \mathrm{g} / \mathrm{g})$, e and f) volumetric production of carotenoids $(\mu \mathrm{g} / \mathrm{mL})$, and $\mathrm{g}$ and $\mathrm{h}) \mathrm{pH}$

ing biomass formation and the one expected by a mass balance model. At $125 \mathrm{~g} / \mathrm{L}$ of glucose in the feed, the biomass formation was lower than the expected one and fermentation products, such as ethanol and acetic acid, accumulated in the culture medium.
With the use of $50 \mathrm{~g} / \mathrm{L}$ of parboiled rice effluent, there was a significant increase of biomass concentration of 1.1 $\mathrm{g} / \mathrm{L}$ and decrease of SPC of $49.2 \mu \mathrm{g} / \mathrm{g}$ (Table 2). Therefore, phosphorus and nitrogen found in this substrate were probably used for cell growth. This result also shows that 


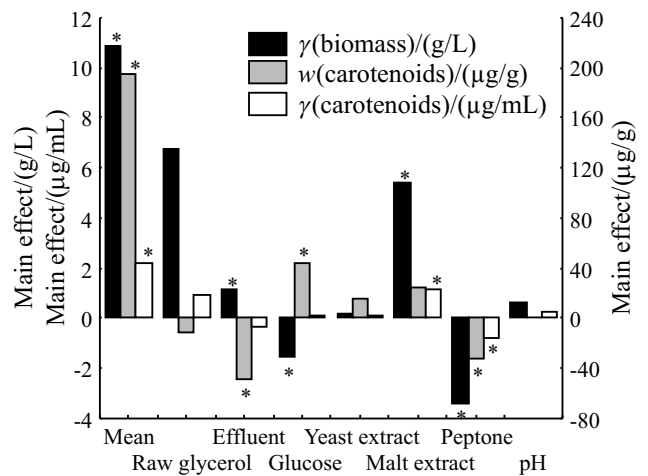

Fig. 2. Main effects of the variables on the biomass concentration $(\mathrm{g} / \mathrm{L})$, specific production of carotenoids $(\mu \mathrm{g} / \mathrm{g})$ and volumetric production $(\mu \mathrm{g} / \mathrm{mL})$ of carotenoids, ${ }^{*}$ significant effect $(\mathrm{p}<0.1)$

carotenogenesis can be stimulated by nitrogen limitation. Vustin et al. (29) suggested that nitrogen in excess in the medium culture can increase cell growth, but suppress the activity of enzymes in carotenoid conversion.

Likewise, increase in the malt extract concentration from 1 to $10 \mathrm{~g} / \mathrm{L}$ resulted in the increase in the effects of all responses, namely biomass concentration, SPC and VPC of $5.4 \mathrm{~g} / \mathrm{L}, 24.0 \mu \mathrm{g} / \mathrm{g}$ and $1.2 \mu \mathrm{g} / \mathrm{mL}$, respectively. However, opposite effects were observed with the increase of peptone concentration, a variable that was studied at the same concentration range as the previous variable: there was a significant decrease in biomass concentration $(3.4$ $\mathrm{g} / \mathrm{L})$, SPC $(32.5 \mu \mathrm{g} / \mathrm{g})$ and VPC $(0.8 \mu \mathrm{g} / \mathrm{mL})$ responses. Furthermore, no significant effect on any response under study was observed when the concentration of the yeast extract increased from the -1 level $(1 \mathrm{~g} / \mathrm{L})$ to the +1 level $(10 \mathrm{~g} / \mathrm{L})$, as well as with the increase in the initial $\mathrm{pH}$ of the culture medium from 4 to 6 .

Rios et al. (16) observed positive effects of the increase in malt extract concentration on carotenoid production but not of the yeast extract concentration when using $P$. rhodozyma in similar culture media without the use of raw glycerol. The yeast extract and other nutrients added to the culture medium did not influence the production of carotenoids by Xanthophyllomyces dendrorhous ENM 5 at $20{ }^{\circ} \mathrm{C}$ and $250 \mathrm{rpm}$. However, contrary results to the ones found in this study were obtained, with an increase in the initial $\mathrm{pH}$ of the culture medium from 4.5 to 6.5 (30). Studies show that the initial $\mathrm{pH}$ of the culture medium for cell growth and production of carotenoids depend on the microbial strain under study (41).

The production of carotenoids using agro-industrial by-products in this study was better than that obtained by Zeni et al. (42) using isolated microorganisms capable of producing carotenoids from soil, leaves, flowers, fruits, agro-industrial waste and decomposed processed products. The isolated microorganisms were cultured on an orbital shaker with $10 \%$ (by mass per volume) inoculum $\left(25^{\circ} \mathrm{C}\right.$ and $180 \mathrm{rpm}$ for $48 \mathrm{~h}$ ) for $120 \mathrm{~h}$ in the dark in $\mathrm{YM}$ medium. A total of 116 microorganisms were isolated (16 yeasts, 65 bacteria and 35 molds). Three yeasts showed great potential to produce red carotenoids in a concentration up to $707-818 \mu \mathrm{g} / \mathrm{L}(99-263 \mu \mathrm{g} / \mathrm{g})$. One mold and two bacteria produced yellow pigments in a concentration ranging from 1063 to $2563 \mu \mathrm{g} / \mathrm{L}$ (239-2310 $\mu \mathrm{g} / \mathrm{g})$.
The Plackett-Burman design was adequate for screening medium culture variables in the production of carotenoids by X. dendrorhous NRRL Y-17268. Increases in raw glycerol and malt extract concentrations were the most important variables for the concomitant increase in cell growth and production of carotenoids. Increase in the peptone concentration influenced cell growth and production of carotenoids negatively. Glucose and parboiled rice effluent showed the opposite effect. The initial $\mathrm{pH}$ of the culture medium and the concentration of yeast extract were not significant $(p<0.1)$ in the responses under investigation.

\section{Conclusions}

The use of the by-products raw glycerol and parboiled rice effluent in the culture medium for carotenoid bioproduction by Xanthophyllomonas dendrorhous NRRL Y-17268 under different conditions was observed. The effects of the concentration of culture medium components were verified in shake flasks by Plackett-Burman design. The maximum value was found at $168 \mathrm{~h}$ with volumetric production of carotenoids of $4.1 \mu \mathrm{g} / \mathrm{mL}(326.8 \mu \mathrm{g} / \mathrm{g})$ in the culture medium containing (in $\mathrm{g} / \mathrm{L}$ ): raw glycerol 10, glucose 10 , yeast extract 10 , malt extract 10 and peptone 1 , at initial $\mathrm{pH}=6$.

\section{Acknowledgements}

The authors would like to thank CAPES (Brazilian Agency for Improvement of Graduate Personnel) and CNPq (National Council of Science and Technological Development) for their financial support.

\section{References}

1. Maldonade IR, Rodriguez-Amaya DB, Scamparini ARP. Carotenoids of yeasts isolated from the Brazilian ecosystem. Food Chem. 2008;107:145-50.

http://dx.doi.org/10.1016/j.foodchem.2007.07.075

2. Bolhassani A, Khavari A, Bathaie SZ. Saffron and natural carotenoids: biochemical activities and anti-tumor effects. BBA - Rev Cancer. 2014;1845:20-30.

http://dx.doi.org/10.1016/j.bbcan.2013.11.001

3. Jomova K, Valko M. Health protective effects of carotenoids and their interactions with other biological antioxidants. Eur J Med Chem. 2013;70:102-10. http://dx.doi.org/10.1016/j.ejmech.2013.09.054

4. Wolak T, Paran E. Can carotenoids attenuate vascular aging? Vasc Pharmacol. 2013;59:63-6. http://dx.doi.org/10.1016/j.vph.2013.07.006

5. Serrão Cabral MM, Cence K, Zeni J, Tsai SM, Durrer A, Foltran LL, et al. Carotenoids production from a newly isolated Sporidiobolus pararoseus strain by submerged fermentation. Eur Food Res Technol. 2011;233:159-66. http://dx.doi.org/10.1007/s00217-011-1510-0

6. Gu Z, Chen D, Han Y, Chen Z, Gu F. Optimization of carotenoids extraction from Rhodobacter sphaeroides. LWT - Food Sci Technol. 2008;41:1082-8. http://dx.doi.org/10.1016/j.lwt.2007.07.005

7. Venil CK, Zakaria ZA, Ahmad WA. Bacterial pigments and their applications. Process Biochem. 2013;48:1065-79. http://dx.doi.org/10.1016/j.procbio.2013.06.006 
8. Silva CM, Borba TM, Burkert CAV, Burkert JFM. Carotenoid production by Phaffia rhodozyma using raw glycerol as an additional carbon source. Int J Food Eng. 2012;8(4). http://dx.doi.org/10.1515/1556-3758.2843

9. Michelon M, Borba TM, Rafael RS, Burkert CAV, Burkert JFM. Extraction of carotenoids from Phaffia rhodozyma: a comparison between different techniques of cell disruption. Food Sci Biotechnol. 2012;21:1-8. http://dx.doi.org/10.1007/s10068-012-0001-9

10. Fonseca RAS, Rafael RS, Kalil SJ, Burkert CAV, Burkert JFM. Different cell disruption methods for astaxanthin recovery by Phaffia rhodozyma. Afr J Biotechnol. 2011;10:1165-71. http://dx.doi.org/10.5897/AJB10.1034

11. Chávez-Cabrera C, Flores-Bustamante ZR, Marsch R, Montes MC, Sánchez S, Cancino-Díaz JC, Flores-Cotera LB. ATP-citrate lyase activity and carotenoid production in batch cultures of Phaffia rhodozyma under nitrogen-limited and nonlimited conditions. Appl Microbiol Biotechnol. 2010;85: 1953-60. http://dx.doi.org/10.1007/s00253-009-2271-6

12. Nghiem NP, Montanti J, Johnston D. Production of astaxanthin from corn fiber as a value-added co-product of fuel ethanol fermentation. Appl Biochem Biotechnol. 2009;154:48-58. http://dx.doi.org/10.1007/s12010-008-8399-5

13. Valduga E, Valério A, Treichel H, Furigo Júnior A, Di Luccio M. Optimization of the production of total carotenoids by Sporidiobolus salmonicolor (CBS 2636) using response surface technique. Food Bioprocess Technol. 2009;2:415-21. http://dx.doi.org/10.1007/s11947-008-0066-x

14. Monks LM, Rigo A, Mazutti MA, Oliveira JV, Valduga E. Use of chemical, enzymatic and ultrasound-assisted methods for cell disruption to obtain carotenoids. Biocatal Agric Biotechnol. 2013;2:165-9. http://dx.doi.org/10.1016/j.bcab.2013.03.004

15. Machado WRC, Burkert JFM. Optimization of agroindustrial medium for the production of carotenoids by wild yeast Sporidiobolus pararoseus. Afr J Microbiol Res. 2015;9:20919. http://dx.doi.org/10.5897/AJMR2014.7096

16. Rios DAS, Borba TM, Kalil SJ, Burkert JFM. Rice parboiling wastewater in the maximization of carotenoids bioproduction by Phaffia rhodozyma. Ciênc Agrotec. 2015:39:401-10. http://dx.doi.org/10.1590/S1413-70542015000400011

17. Cipolatti EP, Bulsing BA, Sá CS, Burkert CAV, Furlong EB, Burkert JFM. Carotenoids from Phaffia rhodozyma: antioxidant activity and stability of extracts. Afr J Biotechnol. 2015; 14:1982-8. http://dx.doi.org/10.5897/AJB2015.14682

18. Ni H, Chen QH, He GQ, Wu GB, Yang YF. Optimization of acidic extraction of astaxanthin from Phaffia rhodozyma. J Zhejiang Univ Sci B. 2008;9:51-9.

http://dx.doi.org/10.1631/jzus.B061261

19. Parajó JC, Santos V, Vázquez M. Optimization of carotenoid production by Phaffia rhodozyma cells grown on xylose. Process Biochem. 1998;33:181-7. http://dx.doi.org/10.1016/S0032-9592(97)00045-9

20. Zhang Y, Rittmann BE, Wang J, Sheng Y, Yu J, Shi H, Qian Y. High-carbohydrate wastewater treatment by IAL-CHS with immobilized Candida tropicalis. Process Biochem. 2005;40: 857-63. http://dx.doi.org/10.1016/j.procbio.2004.02.010

21. Rodrigues MI, Iemma AF. Understanding factorial design. In: Experimental design and process optimization, Boca Raton, FL, USA: CRC Press; 2012. pp. 93-122.

22. AOAC Official Method 972.44. Microbiological Method. Washington, DC, USA: Association of Official Analytical Chemists; 2000 .
23. Rodriguez-Amaya DB. A guide to carotenoid analysis in foods. Washington, DC, USA: ILSI Press; 2001.

24. Chumpolkulwong N, Kakizono T, Nagai S, Nishio N. Increased astaxanthin production by Phaffia rhodozyma mutants isolated as resistant to diphenylamine. J Ferment Bioeng. 1997;83:429-34.

http://dx.doi.org/10.1016/S0922-338X(97)82996-0

25. Domínguez-Bocanegra AR, Torres-Muñoz JA. Astaxanthin hyperproduction by Phaffia rhodozyma (now Xanthophyllomyces dendrorhous) with raw coconut milk as sole source of energy. Appl Microbiol Biotechnol. 2004;66:249-52. http://dx.doi.org/10.1007/s00253-004-1686-3

26. Kusdiyantini E, Gaudin P, Goma G, Blanc PJ. Growth kinetics and astaxanthin production of Phaffia rhodozyma on glycerol as a carbon source during batch fermentation. Biotechnol Lett. 1998;20:929-34.

http://dx.doi.org/10.1023/A:1005445808265

27. Queiroz MI, Lopes EJ, Queiroz Zepka L, Bastos RG, Goldbeck $R$. The kinetics of the removal of nitrogen and organic matter from parboiled rice effluent by cyanobacteria in a stirred batch reactor. Bioresour Technol. 2007;98:2163-9. http://dx.doi.org/10.1016/j.biortech.2006.08.034

28. Chatzifragkou A, Makri A, Belka A, Bellou S, Mavrou M, Mastoridou M, et al. Biotechnological conversions of biodiesel derived waste glycerol by yeast and fungal species. Energy. 2011;36:1097-108. http://dx.doi.org/10.1016/j.energy.2010.11.040

29. Vustin MM, Belykh EN, Kishilova SA. Relationship between astaxanthin production and the intensity of anabolic processes in the yeast Phaffia rhodozyma. Microbiology. 2004; 73:643-9. http://dx.doi.org/10.1007/s11021-005-0004-0

30. Liu YS, Wu JY. Optimization of cell growth and carotenoid production of Xanthophyllomyces dendrorhous through statistical experiment design. Biochem Eng J. 2007;36:182-9. http://dx.doi.org/10.1016/j.bej.2007.02.014

31. Chociai MB, Machado IMP, Fontana JD, Chociai JG, Busato SB, Bonfim TMB. Cultivation of Phaffia rhodozyma (Xanthophyllomyces dendrorhous) yeast in discontinuous system to obtain astaxanthin. Rev Braz Cienc Farm. 2002;38:457-62 (in Portuguese). http://dx.doi.org/10.1590/S1516-93322002000400008

32. Makri A, Fakas S, Aggelis G. Metabolic activities of biotechnological interest in Yarrowia lipolytica grown on glycerol in repeated batch cultures. Bioresour Technol. 2010;101:2351-8. http://dx.doi.org/10.1016/j.biortech.2009.11.024

33. Marova I, Certik M, Breierova E. Production of enriched biomass by carotenogenic yeasts - application of whole-cell yeast biomass to production of pigments and other lipid compounds. In: Matovic D, editor. Biomass detection, production and usage. Rijeka, Croatia: InTech; 2011. pp. 345-84. http://dx.doi.org/10.5722/19235

34. Petrik S, Marova I, Haronikova A, Kostovova I, Breierova E. Production of biomass, carotenoid and other lipid metabolites by several red yeast strains cultivated on waste glycerol from biofuel production - a comparative screening study. Ann Microbiol. 2013;63:1537-51. http://dx.doi.org/10.1007/s13213-013-0617-x

35. Bellou S, Moustogianni A, Makri A, Aggelis G. Lipids containing polyunsaturated fatty acids synthesized by zygomycetes grown on glycerol. Appl Biochem Biotechnol. 2012;166: 146-58.

http://dx.doi.org/10.1007/s12010-011-9411-z

36. Papanikolaou S, Beopoulos A, Koletti A, Thevenieau F, Koutinas AA, Nicaud JM, et al. Importance of the methyl-citrate cycle on glycerol metabolism in the yeast Yarrowia lipolytica. J Biotechnol. 2013;168:303-14. http://dx.doi.org/10.1016/j.jbiotec.2013.10.025 
37. Bellou S, Makri A, Triantaphyllidou IE, Papanikolaou S, Aggelis G. Morphological and metabolic shifts of Yarrowia lipolytica induced by alteration of the dissolved oxygen concentration in the growth environment. Microbiology. 2014; 160:807-17.

http://dx.doi.org/10.1099/mic.0.074302-0

38. Deken RH. The Crabtree effect: a regulatory system in yeast. Microbiology. 1966;44:149-56.

http://dx.doi.org/10.1099/00221287-44-2-149

39. Rivaldi JD, Sarrouh BF, Fiorilo R, Silva SS. Biotechnological strategies for glycerol utilization derived from biodiesel production. Biotec Ciên Desenvol. 2007;37:44-51 (in Portuguese).
40. Reynders MB, Rawlings DE, Harrison STL. Demonstration of the Crabtree effect in Phaffia rhodozyma during continuous and fed-batch cultivation. Biotechnol Lett. 1997;19:549-52. http://dx.doi.org/10.1023/A:1018341421122

41. Valduga E, Tatsch PO, Tiggemann L, Treichel H, Toniazzo G, Zeni J, et al. Carotenoids production: microorganisms as source of natural dyes. Quim Nova. 2009;32:2429-36 (in Portuguese).

http://dx.doi.org/10.1590/s010-40422009000900036

42. Zeni J, Colet R, Cence K, Tiggemann L, Toniazzo G, Cansian $\mathrm{RL}$, et al. Screening of microorganisms for production of carotenoids. CyTA - J Food. 2011;9:160-6. http://dx.doi.org/10.1080/19476337.2010.499570 